NASA Technical Memorandum 87319

\title{
Design Considerations for Advanced Battery Concepts
}

Harold F. Leibecki and Lawrence H. Thaller

Lewis Research Center

Cleveland, Ohio

(NASA-TH-87319) LESIGN CONSIDERATIONS FOB ADVANCED BATTERY CONCEPTS (NASA) 16 p

N86-31 981

CSCL $10 \mathrm{C}$
G3/44
Unclas
43503

Prepared for the

Third Space Systems Technology Conference sponsored by the American Institute of Aeronautics and Astronautics

San Diego, California, June 9-12, 1986 


\section{DESIGN CONSIDERATIONS FOR ADVANCED BATTERY CONCEPTS}

Harold F. Leibecki and Lawrence H. Thaller

National Aeronautics and Space Administration

Lewis Research Center

Cleveland, oh io 44135

\section{SUMMARY}

A mathematical representation for the charge and discharge of a sodiumsulfur cell is developed. These equations are then used as the basis for a computerized model to examine the effects of cell arrangement in the design of a large multi-kilowatt battery from a group of hypothetical individual cells with known variations in their ampere hour capacity and internal resistance. The cycling characteristics of 216 individual cells arranged in six different configurations are evaluated with the view towards minimizing the adverse effects that are introduced due to the stoichastic aspects of groupings of cells, as well as the possibllity of cell fallures in both the open and shorted mode. Although battery systems based on sodium-sulfur cells are described in this example, any of the newer electrochemical systems can be fitted into this framework by making appropriate modifications to the basic equations.

\section{INTRODUCTION}

The sodium-sulfur cell is comprised of liquid sodium and sulfur electrodes separated by a solid sodium beta'"-alumina electrolyte. This secondary cell is characterized by its high theoretical energy density ( $760 \mathrm{Wh} / \mathrm{kg})$, coulombic efficlency (100 percent), and current densities (ref. 1), as well as an operating temperature of $350{ }^{\circ} \mathrm{C}$. Since its inception by Kummer and Weber in 1967 (ref. 2) the cell has reached a fairly advanced state of development (ref. 3). Improvements in cell components and production control have lengthened the life of sodium-sulfur cells to an average cell life of about 1500 cycles (ref. 4). With anticipated increases in cell life, due to separator advancements and quality control, large scale battery development is now a reality. The build-up of a large (multi-kilowatt) battery necessitates the use of a large number of single cells electrically connected to produce the required voltage and current. The use of a large number of cells allows an increasing number of options in selecting the manner in which cells can be arranged to obtain the desired battery requirements.

There are several characteristics that are currently associated with the sodium sulfur technology that makes it desirable to examine, on a cell-by-cell basis, individual cell operation within a completed battery. It has been suggested (ref. 5) that there may be certain upper limits to the current density within the ceramic separators that are consistent with long cycle and calendar $1 i f e$. Likewise, there are also limits to the depth of discharge as a consequence of solubility limits associated with the electroactive species. Further, the random breakage of ceramics due to heating and cooling or as a consequence of type I or type II fallures (ref. 6) results in cells that are, in effect, shorted. The fuse link technique used to circumvent problems caused by increased currents within nearby cells has the drawback of distributing the current flow in nearby battery elements. The use of inexpensive computer techniques to model, as a first approximation, these very complex interactions 
will help in the selection of one battery configuration over others that from a power standpoint may be equivalent.

\section{CELL OPERATION}

The E.M.F. of a sodium-sulfur cell is characterized by the composition of the sodium sulfide species present. Figure 1(a) (ref. 7) shows the open circuit potential as a function of composition. This can be directly related to the depth-of-discharge as shown in figure $1(b)$. The open circuit potential remains constant at $2.078 \mathrm{~V}$ during the initial discharge to a composition of $\mathrm{Na}_{2} \mathrm{~S}_{5}, 19$. During this period the reactant sulfur and product sodium polysulfide exist as two immiscible liquids $\left(L_{1}\right.$ and $\left.L_{2}\right)$. Upon further reduction of the polysulfide, a single liquid exists $\left(L_{2}\right)$ which has a linear decrease of potential until it reaches a composition of $\mathrm{Na}_{2} \mathrm{~S}_{2} .98$ and a voltage of $1.78 \mathrm{~V}$. This is the practical limit of discharge since further reduction results in the precipitation of $\mathrm{Na}_{2} \mathrm{~S}_{2}$. Using this relationship of 1 mole of sulfur to 0.671 moles of sodium as a depth-of-discharge equal to 100 percent, the open circuit potential of a sodium-sulfur cell can be expressed as a function of the amount of sulfur reduced. This can be stated mathematically as:

$$
V=2.078-0.296 \star F r_{2}+0.05 \star \operatorname{Exp}(-95.25 \star D 0 D)
$$

where: 2.078 is the open-circuit voltage of the sulfur-sodium pentasulfide $\mathrm{mixture.} 0.296$ is the rate of change of open-circuit voltage due to the reduction of the polysulfide from $\mathrm{Na}_{2} \mathrm{~S}_{5} .19$ to $\mathrm{Na}_{2} \mathrm{~S}_{2} .98$. Fr 2 is the amount of polysulfide reduced from $\mathrm{Na}_{2} \mathrm{~S}_{5} .19$ to $\mathrm{Na}_{2} \mathrm{~S}_{2} .98$. The exponential term accounts for the change occurring due to pure suifur going to a mixture of sulfur and a small amount of sodium pentasulfide. The discharge or charge voltage will also be governed by the resistance and current. These can be incorporated into the equation for discharge and charge as shown in equations (2) and (3).

Discharge:

$$
E=2.078-0.296 \star F r_{2}-I \star R+0.05 \star E x p(-95.25 \star D O D)
$$

Charge:

$$
E=2.078-0.296 \star F r_{2}+I \star R+0.05 \star E \times p(-95.25 \star D 0 D)
$$

where: I is the current in amperes; $R$ is the resistance in ohms. All the other terms are the same as equation (1).

The equations for charge and discharge of the sodium-sulfur cell describes the actual performance very well as shown in figures $2(a)$ and (b). Figure 2(a) depicts the actual and calculated potential or a function of state of charge while figure $2(b)$ shows the difference in potential between the actual and calculated potential as a function of state of charge. Figures $2(a)$ and (b) are representative of four sodium-sulfur cells tested by the Wright Aeronautical Laboratory (ref. 8). The mean variation between the equation and data points is $2.7 \mathrm{mV}$. In this set of cells it was found that the charging resistance was larger than the discharge resistance and could be expressed by equation (4). 


$$
\text { ChrgR }=-25.31+41.14 * 01 \text { SchR }
$$

where: ChrgR is the charge resistance in mOhms; DischR is the discharge resistance in mohms.

Karas (ref. 9) has reported an increase in resistance on charging as due to the presence of sulfur at the electrolyte interface and Staikov (ref. 10) has reported an increase of resistance on discharging caused by a film being formed on the sodium side of the electrolyte. Both authors report observations of cells with equal charge and discharge resistance.

\section{COMPUTER SIMULATION}

Using these charge and discharge equations, a computer program was written to allow multi-cell cycling.

\section{Cell Discharge Logic}

Each cell is considered as an individual with its unique capacity and resistance. At the first level all cells connected in parallel are calculated using the discharge equation with the requirements that the potential of the cells are equal and the algebraic sum of the current is equal to the current through the module. The second level sums the potentials for each set of parallel groups to obtain the potential of a module. The third level calculates the current through each module with the requirement that the potential of each module is equal and the sum of the currents through each module equals the desired discharge current for the battery. The sets of equations requiring Kirchhoff's laws to be observed are solved to give a potential current relationship for each cell at a given instant in the discharge. By multiplying each cell's discharge current by a fraction of the discharge time, an incremental discharge proftle is estabilished. By combining the incremental discharges in an integrative process, the end of discharge potential, current, and DOD of each cell is obtained.

\section{Cell Charge Logic}

The same procedure is used as in the discharge using the charging equation. The end of charge is selected depending upon the conditions:

(1) Normal cycling (no shorted or open cells); (a) when any cell reaches 100 percent of charge. No over charge allowed. Or, (b) when a cell reaches $3.0 \mathrm{~V}$. Or, (c) when 115 percent of the discharge capacity has been returned.

(2) Shorted cell cycling. Normal cycling: occurs for seven cycles, then a cell is shorted with a resistance equal to its nonshorted resistance. (a) when a cell not in the shorted parallel group reaches 100 percent of charge. Or, (b) when a cell reaches $3.0 \mathrm{~V}$. Or, (c) when 115 percent of the discharge capacity has been returned.

(3) Open cell cycling. Normal cycling occurs for seven cycles, then a cell is opened. For the spectal case of one cell strings connected in 
paraliel, the entire string is excluded. Otherwise only the cell is excluded from calculations. End of charge is the same as normal cycling.

\section{A SODIUM-SULFUR BATTERY}

Using the relationship between cell voltage, sulfur composition and cell resistance, the effect of cell electrical connection was evaluated for a simulated set of 216,150 Ah cells. These cells, produced by the Yuasa Battery Company (ref. 11), have cell capacities between 100 and 160 Ah and cell internal resistance between 6 and $13 \mathrm{~m}$. Figures $3(\mathrm{a})$ to (c) show the histograms for 353 production cells and a simulated set using a beta distribution. The simulated capacity and resistance distributions were then paired so that the cells with the highest capacities would have the lowest resistance. From this group 216 of the highest capacity cells were chosen for use in the simulated battery. The simulated battery was configured so as to have an open circuit voltage of $24.936 \mathrm{~V}$ when fully charged, in keeping with that proposed by Kita, et al. This required that 12 cells be connected in series. Figure 4 shows the nomenclature used to describe the cell electrical connections. A battery is composed of modules connected in parallel. Each module is composed of bundles of cells which are connected in series and each bundle is composed of cells connected in parallel. Since it was predetermined that the battery would have open circuit voltage of 24.936 or 12 cells connected in series, this set the number of bundles at 12 . Each bundle could then have either 1,2,3,6, 9, or 18 cells in parallel. The number of modules would then be $18,9,6,3,2$, or 1 , respectively.

For the purpose of simulated cycling, the battery was discharged to 70 percent of its nominal capacity in $1.6 \mathrm{hr}$ and charged at 25 percent of this discharge rate. Since no information was avallable for the charging or discharge resistance, they were both set equal to the reported internal resistance $(7.71 \pm .46 \mathrm{~m} \Omega)$.

Figure 5 shows the cell results of simulated battery cycling at 1191 amperes discharge for $1.6 \mathrm{hr}$ and 298 amperes charge. As can be seen, the manner in which the cells are arranged has an effect on the variation of the individual cell discharge parameters. The worst case occurs for two cells connected in parallel. The other configurations show that by increasing the parallel cell connections from 3 to 18 , individual cell current variation increases relative to one cell strings, while the variation of cell DOD and voltage decreases. Battery cycle life would improve if both current and DOD varlation could be minimized. Since it is impossible to arrange the cells so as to obtain this minimum, a configuration with six or more cells in parallel provides the best compromise.

\section{SODIUM-SULFUR BATTERY WITH A SHORTED CELL}

Cracked separator ceramics have been a long term problem associated with these cells. They result in a "shorted" cell. The "soft" shorts that usually preceds this failure is thought to be related in part to the current density at which the individual ceramic is operating (ref. 12). To simulate the operating conditions of a battery with a shorted cell, one cell was arbitrarily chosen and assigned a voltage equal to zero. The internal resistance of the shorted cell was kept equal to its unshorted value. This is in effect 
replacing the cell with a resistor. The battery was allowed to reach cycling equilibrium ( 7 cycles) before the short was introduced.

One cell per bundle (single cell strings) represents a special case. During discharge the current does not change appreciably between shorted and normal operation ( 53 and $65 \mathrm{~A}$, respectively). During charge, the current in the shorted case is larger than normal ( 31 and $10 \mathrm{~A}$, respectively). These differences are small enough so as to preclude any destructive effect. The lower discharge current and higher charging currents produce a situation in which the module (string) with the shorted cell has a lower DOD on discharge and a higher rate of recharge. These two effects cause the other modules to go to higher and higher DODS. This can be remedied by switching out the module with the shorted cell when it reaches the fully charged state.

All configurations with cells connected in parallel $(2,3,6,9$, and 18) exhibit a simllar trend; the shorted cell has sufficient current flowing through it to cause serious problems. Figure 6 shows the exponential decrease of current through the shorted cell as the number of cells in parallel is increased. The current being $574,300,251,200$, and $219 \mathrm{~A}$ for $2,3,6,9$, and 18 cells in parallel, respectively. This current flow, if not sufficient to thermally destroy the cell, will create thermal control problems. Fusible links have been suggested as a means of controlling the excessive current flow through a shorted cell.

\section{SODIUM-SULFUR BATTERY WITH AN OPEN-CIRCUITED CELL}

If a fusible link is used to protect the battery from shorted cells, a condition then exists in which one cell is missing from the bundle. To simulate a battery operating under these conditions, the current and voltage calculations are performed with one cell omitted.

Again the case of a one-cell bundle is unique. In this configuration when a cell fallure causes an open circuit, the entire module (string) is lost. For simulation of this case, the battery with one less module (17 rather than 18) was used.

Except for the case of two and three cells in parallel, there is no inherent problem of operation of the battery with one cell open-circuited. The current through the remaining cells in the module (same as through each bundle in the module) is divided between the good cells and varies from 122 to $70 \mathrm{~A}$ for two and 17 cells in parallel, respectively. For the case of one cell per bundle, the current is increased by $4 \mathrm{~A}(1191 / 17)$ to $70 \mathrm{~A}$. This compares to 66 A for normal cell discharge. This relation is shown in figure 7.

Although the current flow is not excessive, except perhaps for the case of two cells in parallel (122 versus $66 \mathrm{~A})$, it is the voltage of the bundle (cells in parallel) that is most effected. For the case of one cell per bundle (single cell strings), the voltage drop is not significant since only an additional $4 \mathrm{~A}$ needs to be supplied by each module. The difference is 1.50 and $1.53 \mathrm{~V}$ for the open and normal operation, respectively. For multiple cells in parallel, the voltage loss is greatest for the fewest cells in parallel (two parallel cells). The bundle voltage for $2,3,6,9$, and 18 cells in parallel is $1.13,1.35,1.48,1.52$, and $1.55 \mathrm{~V}$, respectively. This compares to a 
voltage of $1.58,1.59,1.57,1.58$, and $1.58 \vee$ for normal operation, respectively. This effect is shown in figure 8 .

\section{CONCLUSIONS}

In multi-k llowatt battery systems, the number of cell arrangements possible increases to a point where pen and paper calculations become impractical to evaluate a system design. The knowledge base of a battery is the single ce11. By coupling mathematical equations that describe the effect of current flowing into or out of a cell, electrical circuitry equations, and the power of the computer, inroads into system design can be made.

Using a design criteria of $30 \mathrm{~kW}$ with a $24 \mathrm{~V}$ open circuit potential and no single-point fallures, a battery was designed which required 216 individual sodium-sulfur cells. These cells could be arranged in six different ways. An equivalent battery could be constructed by wiring $1,2,3,6,9$, or 18 cells in parallel and then connecting 12 parallel groups in series.

By the use of a set of simple but utilitarian equations describing the sodium-sulfur cell, it was shown that:

(1) The arrangement of cells in parallel-series configuration has a meaningful effect upon how each cell functions.

(2) The resulting performance with one cell shorted produces excessive current flow in all arrangements of cells in parallel. The battery can be protected from the shorted cell by fusible links. Single cell strings connected in parallel produce a situation which, if not protected by sensors and switches, will result in total battery fallure.

(3) An open circuited cell produces a condition where the current is shared proportionately by the remaining parallel arrangement.

For a system that will function with a single point fallure and not require sensors and switches, the battery would have to be constructed with 6 cells in parallel, 12 bundles in series, and 3 modules connected in parallel.

\section{REFERENCES}

1. Cairns, E.J., "Advanced Electrochemical Energy Storage Systems," Lawrence Berkeley Laboratory, LBL-17058, Dec. 1983.

2. Kummer, J.T. and Weber, N. in "Sodium-Sulfur Secondary Battery," SAE Paper $670179,-1967$.

3. Sudworth, J.L. and Tilley, A.R., The Sulfur Electrode-Fused Salts and Solid Electrolytes, R.P. Tischer, Editor, Academic Press, New York, 1983, p. 235 .

4. Kalhammer, F., in Beta Battery Development, "EPRI Journal, vol. 8, No.4, May 1983, pp. 52-54. 
5. Buechele, A.C., DeJonghe, L.C., and Hitchcock, D., "Degradation of Sodium B' 'Alumina: Effect of Microstructure," Journal of the Electrochemical Society, vol. 130, no. 5, May 1983, pp. 1042-1049.

6. Mallhe, C.C., "Electrochemical Processes at The Sodium B"'Alumina Interface," M.S. Thesis, University of California, Lawrence Berkeley Laboratory, May 1984, pp. 12-14. (LBL-17687)

7. Topouzian, A., "Research on Electrodes and Electrolyte for the Ford SodiumSulfur Battery," Annual Report for June 30, 1976 to Oct. 31, 1977, Ford Motor Co., Dearborn, MI, Apr. 1978. (PB-301409)

8. Allen, D.M., Dueber R.E., and Fritts, D.H., "Life Cycle Testing of SodiumSulfur Satellite Battery Ce11s," Energy for the Twenty-First Century, vo1. 1., SAE P-164, SAE, Warrenda1e, PA, 1985, PP. 305-309.

9. Karas, B.R., "Interpretation of Sodium-Sulfur Cell Characteristics Using an Alternating Current Resistance Technique," Journal of the Electrochemical Society, vol. 132, no. 6, June 1985, pp. 1261-1266.

10. Staikov, G., Yankulov, P.D., Savova-Stoynov, B.S., and Stoynov, Z.B., "Measurements of ac Impedance of Sodium-Sulfur Cells With Symmetric and Asymmetric Resistance Behaviour," Journal of Applied Electrochemistry, vol. 15, no. 6, Nov. 1985) pp. 895-900.

11. Kita, A., Nomura, E., Matsui, K., and Takashima, K., "Current Status of Deve lopment of $10 \mathrm{kw} \mathrm{Na/S} \mathrm{Battery,"} \mathrm{Energy} \mathrm{for} \mathrm{the} \mathrm{Twenty-First} \mathrm{Century.}$ vo1. 2, SAE P-164, SAE, Warrendale, PA, 1985, Pp. 115-119.

12. Rizzo, R.A., Towle, W.L., and McClanaham, M.L., Handbook of Batteries and Fuel Cells, David Linden, Editor, McGraw-Hill Book Co., New York, 1984, p. 32 . 


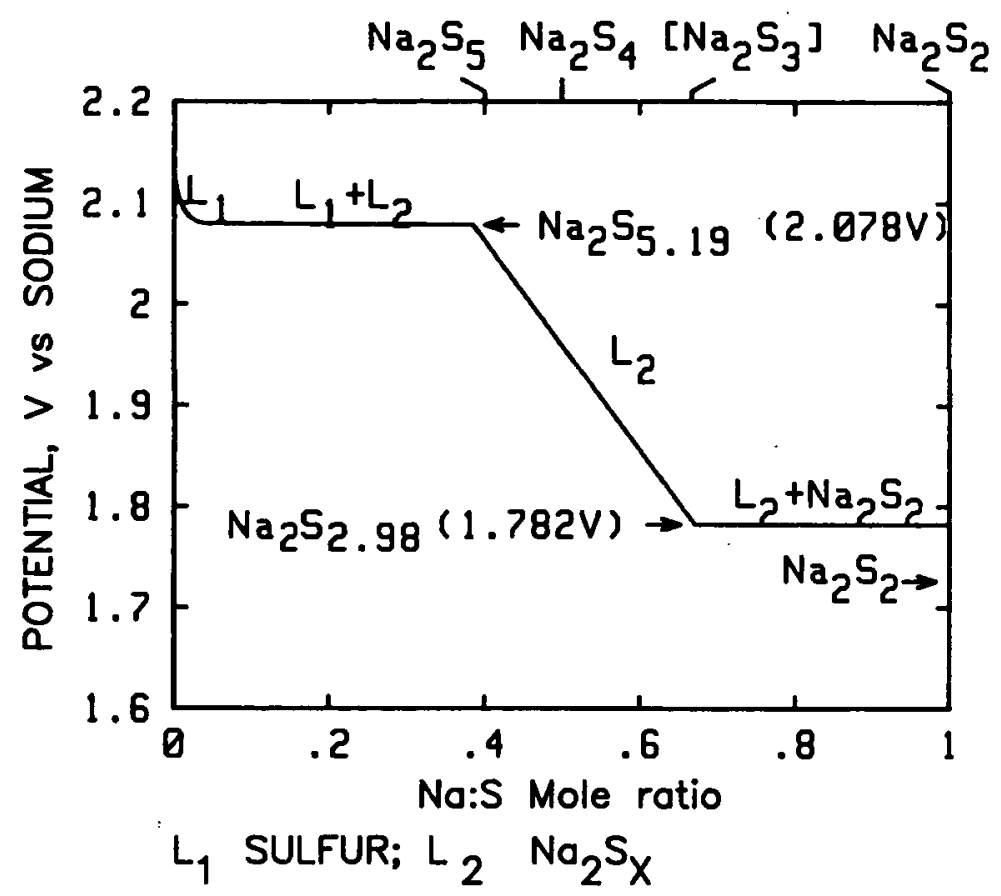

Fig. 1a Open circuit potential as a function of composition.

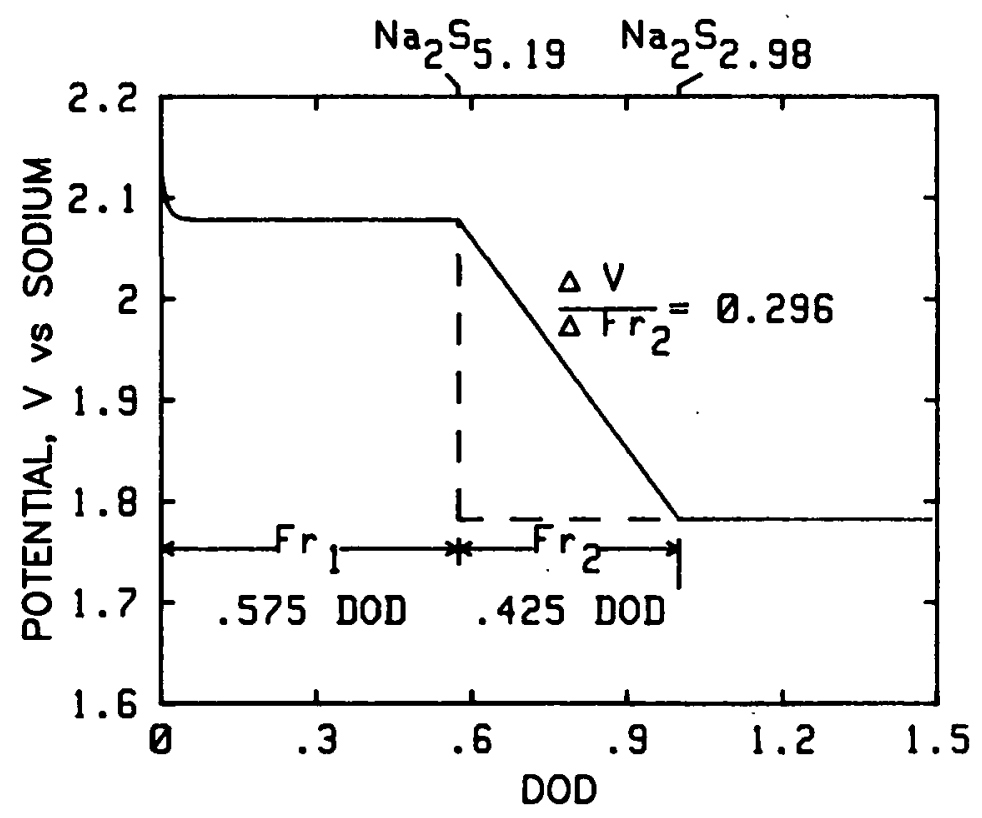

Fig. 1b Open circuit potential as a function of DOD 


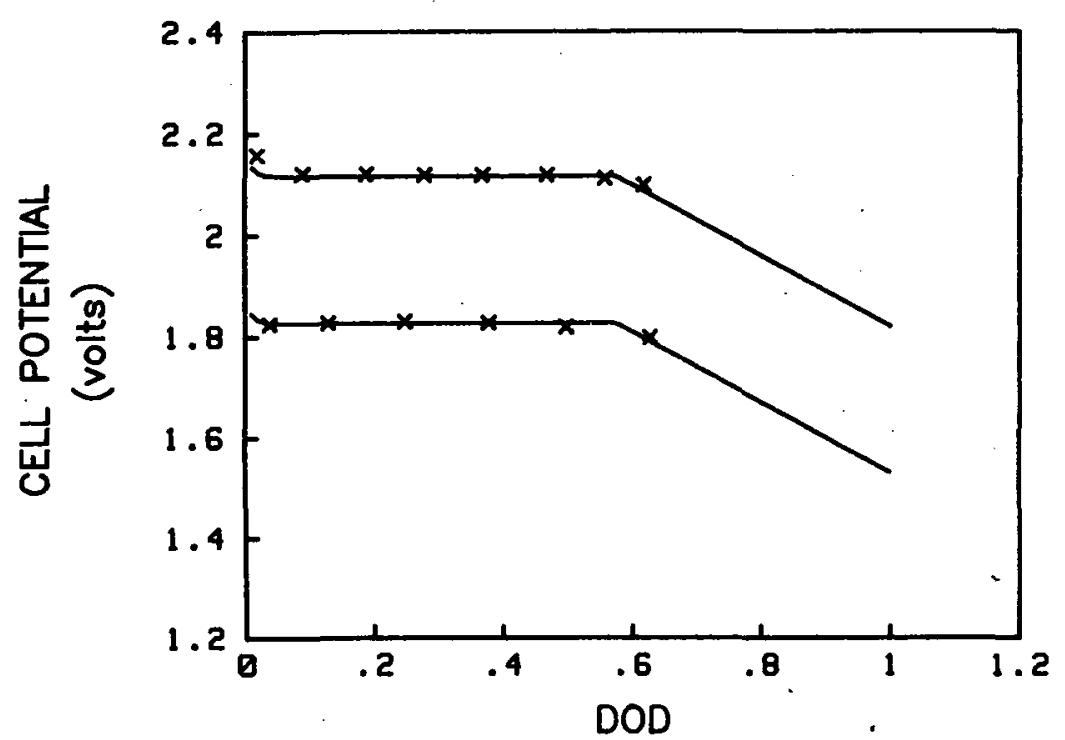

Fig. 2a Comparison of experimental data and model; $x=$ experimental dato $=$ model.

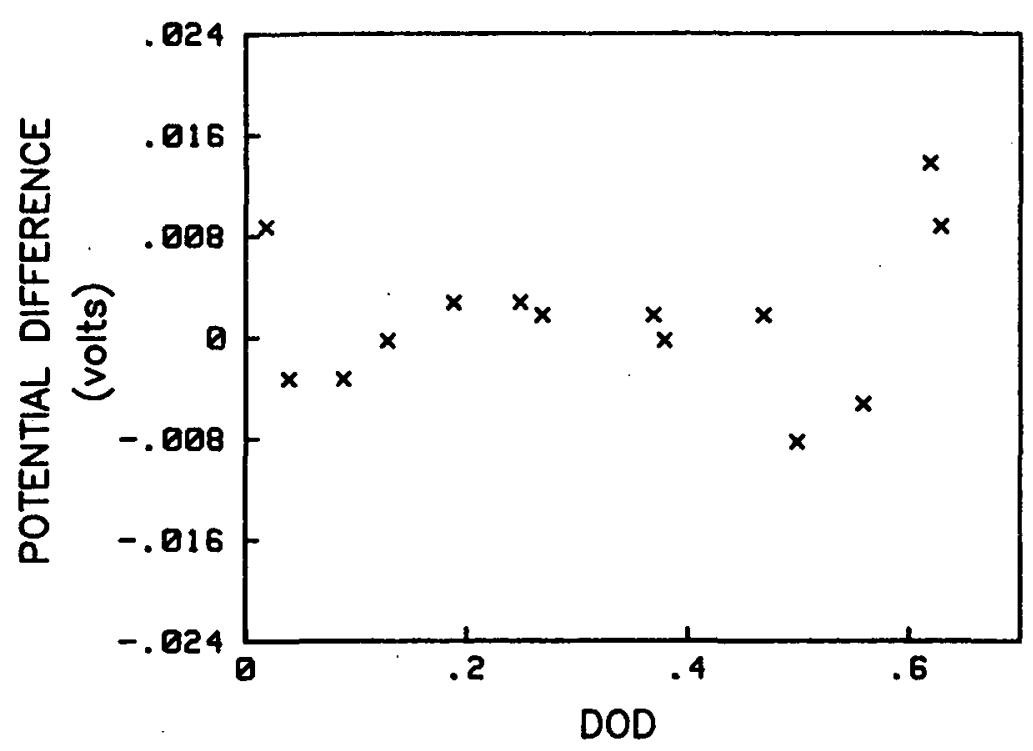

Fig. 2b Difference between experimental and calculated voltage. 


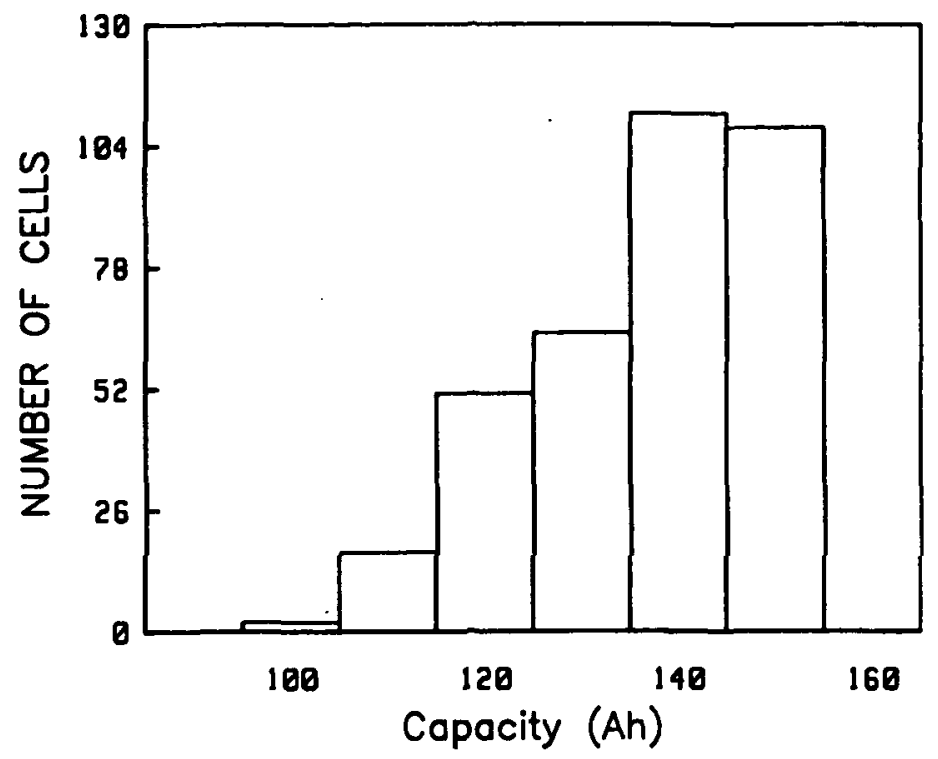

Fig. 3a Histogram of cell capacity for synthetic cycling.

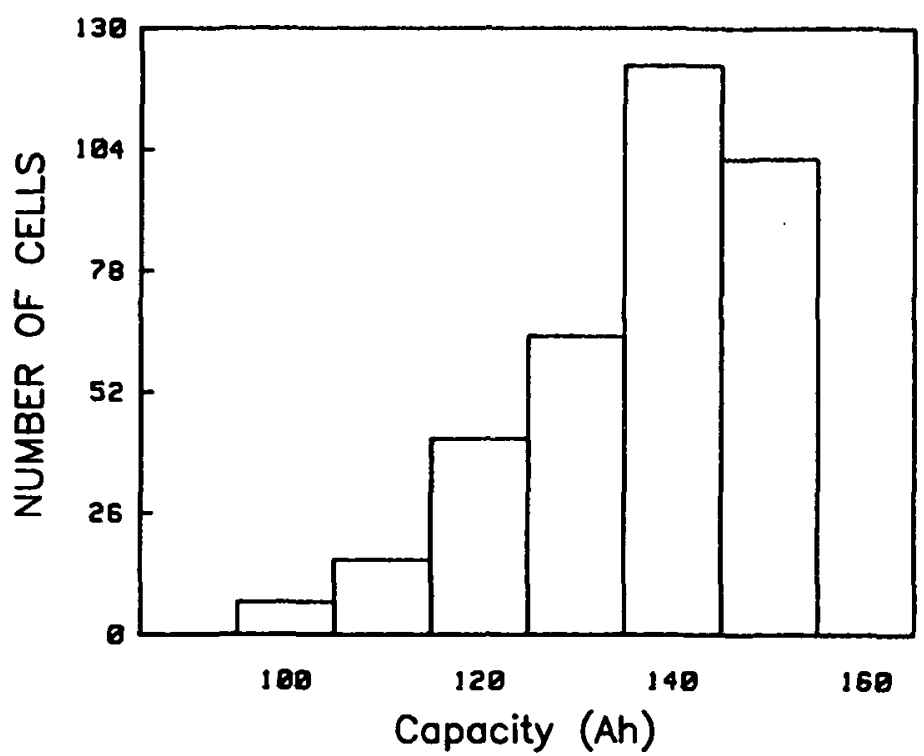

Fig. 3b Histogram of cell capacity from the literature. (Ref. 11) 


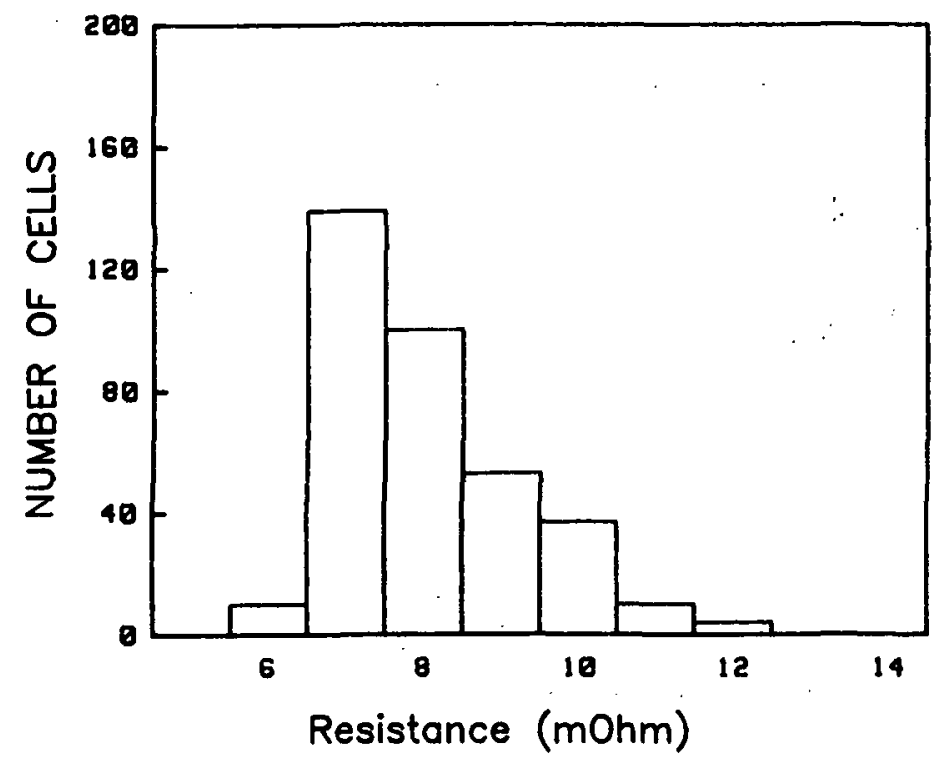

Fig. 3c Histogram of cell resistance for synthetic cycling.

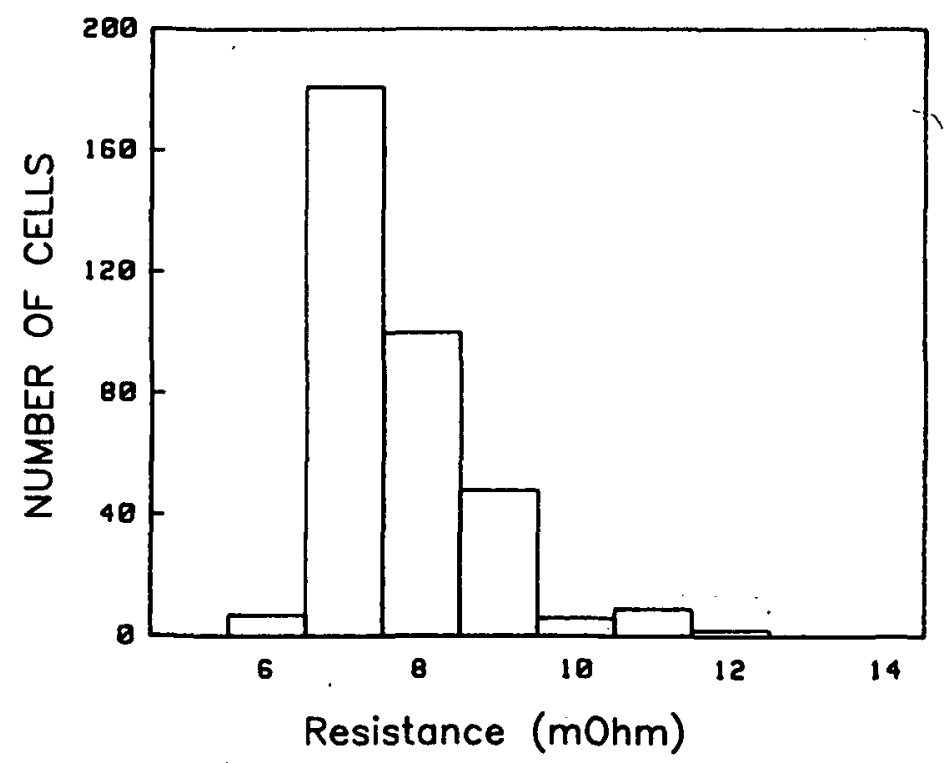

Fig. 3d Histogram of cell resistance from the literoture. (Ref. 11) 


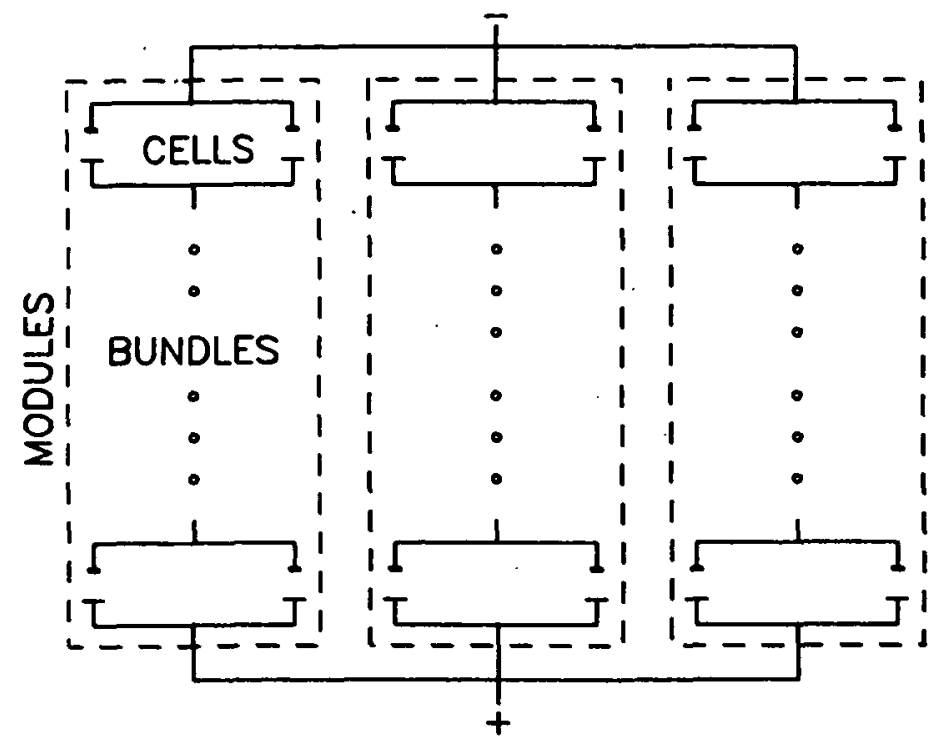

Fig. 4 Battery configuration nomenclature

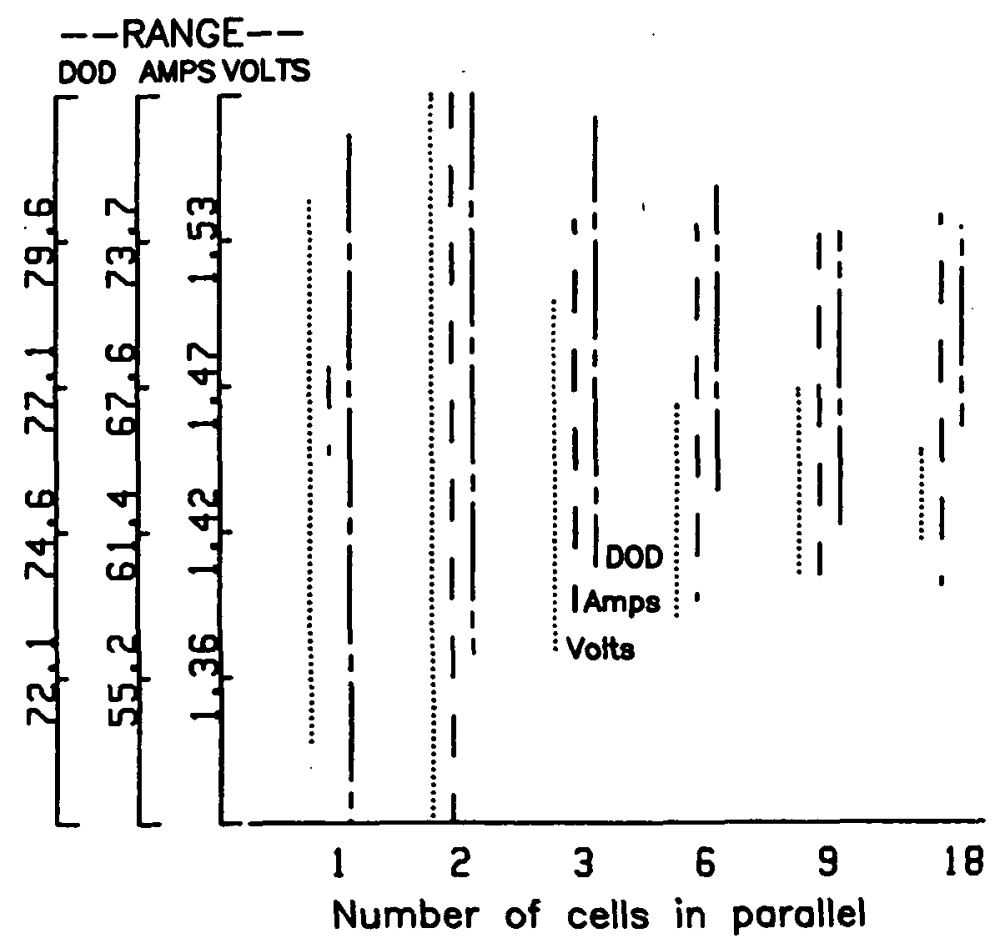

Fig. 5 Voriation of cell voltage, current and DOD due to configuration. 


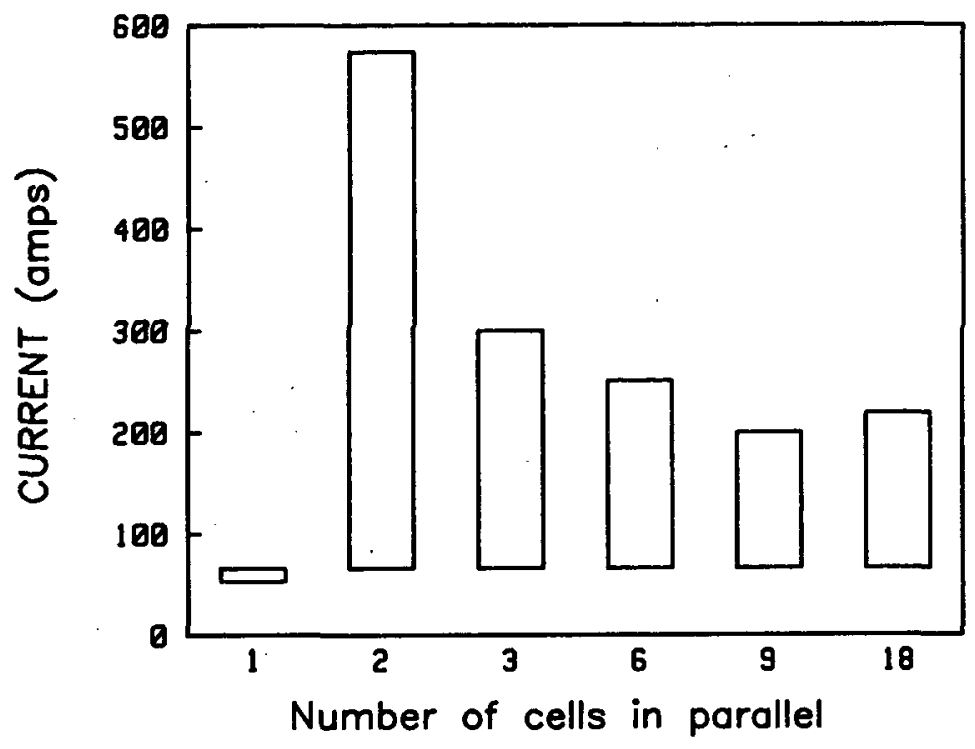

Fig. 6 Current through shorted cell.

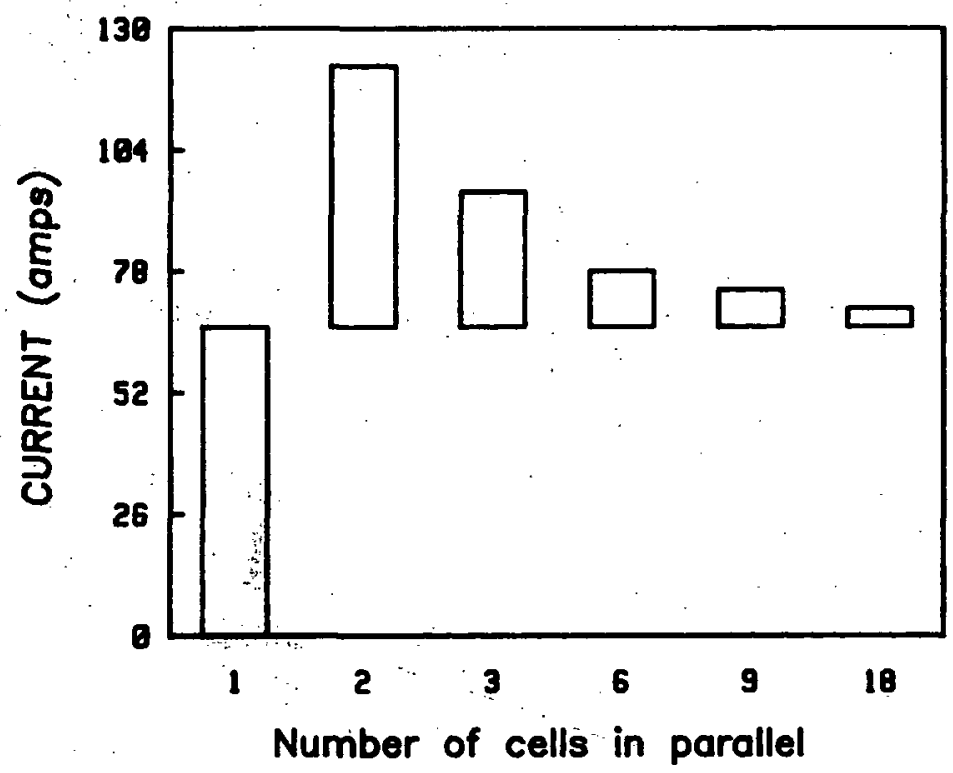

Fig. 7 Current through effected branch with an open circuited cell. 


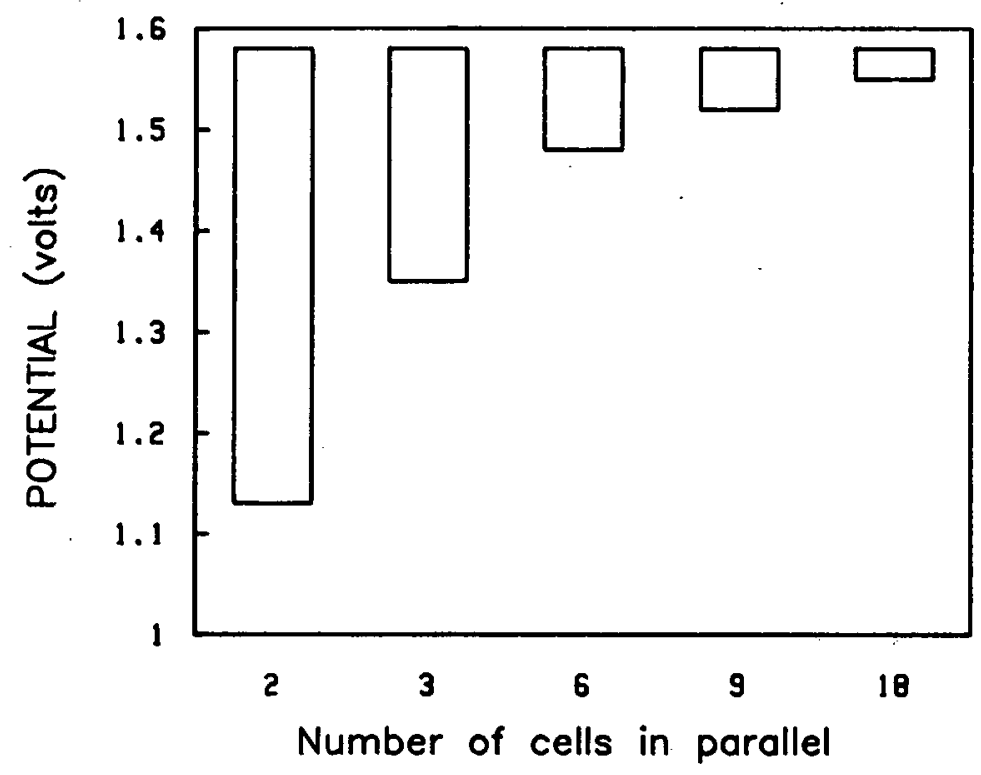

Fig. 8 Potential of parallel branch with an open circuited cell. 


\begin{tabular}{|c|c|c|}
\hline $\begin{array}{l}\text { 1. Report No. } \\
\text { NASA TM-87379 }\end{array}$ & 2. Government Accession No. & 3. Recipient's Catalog No. \\
\hline \multirow{2}{*}{\multicolumn{2}{|c|}{$\begin{array}{l}\text { Design Considerations for Advanc } \\
\text { Concepts }\end{array}$}} & 5. Report Date \\
\hline & & $\begin{array}{l}\text { 6. Performing Organization Code } \\
506-41-21\end{array}$ \\
\hline \multirow{2}{*}{\multicolumn{2}{|c|}{$\begin{array}{l}\text { 7. Author(s) } \\
\text { Harold F. Leibecki and Lawrence H. Thaller }\end{array}$}} & $\begin{array}{l}\text { 8. Performing Organization Report No. } \\
\text { E-3055 }\end{array}$ \\
\hline & & 10. Work Unit No. \\
\hline 9. Performing Organization Name and Address & & \multirow[b]{2}{*}{ 11. Contract or Grant No. } \\
\hline \multicolumn{2}{|c|}{$\begin{array}{l}\text { National Aeronautics and Space Administration } \\
\text { Lewis Research Center } \\
\text { Cleveland, Ohio } 44135\end{array}$} & \\
\hline \multirow{2}{*}{\multicolumn{2}{|c|}{$\begin{array}{l}\text { 12. Sponsoring Agency Name and Address } \\
\text { National Aeronautics and Space Administration } \\
\text { Washington, D.C. } 20546\end{array}$}} & \\
\hline & & 14. Sponsoring Agency Code \\
\hline \multirow{2}{*}{\multicolumn{3}{|c|}{$\begin{array}{l}\text { 15. Supplementary Notes } \\
\text { Prepared for the Third Space Systems Technology Conference, sponsored by the } \\
\text { American Institute of Aeronautics and Astronautics, San Diego, California, } \\
\text { June } 9-12,1986 .\end{array}$}} \\
\hline & & \\
\hline \multicolumn{3}{|c|}{$\begin{array}{l}\text { 16. Abstract } \\
\text { A mathematical representation for the charge and discharge of a sodium-sulfur } \\
\text { cell is developed. These equations are then used as the basis for a computerized } \\
\text { model to examine the effects of cell arrangement in the design of a large multi- } \\
\text { kilowatt battery from a group of hypothetical individual cells with known varia- } \\
\text { tions in their ampere hour capacity and internal resistance. The cycling } \\
\text { characteristics of } 216 \text { individual cells arranged in six different configurations } \\
\text { are evaluated with the view towards minimizing the adverse effects that are } \\
\text { introduced due to the stoichastic aspects of groupings of cells, as well as the } \\
\text { possibility of cell failures in both the open and shorted mode. Although battery } \\
\text { systems based on sodium-sulfur cells are described in this example, any of the } \\
\text { newer electrochemical systems can be fitted into this framework by making } \\
\text { appropriate modifications to the basic equations. }\end{array}$} \\
\hline \multicolumn{3}{|l|}{ 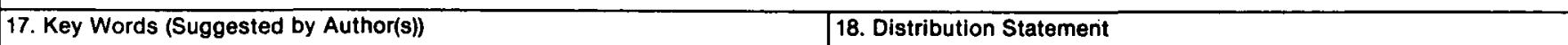 } \\
\hline $\begin{array}{l}\text { Sodium-sulfur; Battery cycling; } \\
\text { Computer simulation }\end{array}$ & $\begin{array}{l}\text { Unclassified - unlimite } \\
\text { STAR Category } 44\end{array}$ & \\
\hline $\begin{array}{l}\text { 19. Security Classif. (of this report) } \\
\text { Unc lass if i ed }\end{array}$ & $\begin{array}{l}\text { page) } \\
\text { sified }\end{array}$ & 22. Price* \\
\hline
\end{tabular}

*For sale by the National Technical Information Service, Springfield, Virginia 22161 
National Aeronautics and Space Administration

Lewis Research Center Cleveland. Ohio 44135

Onicial Business

Penaly for Pivate Use 5300
SECOND CLASS MAIL

AODRESS CORRECTION REQUESTED

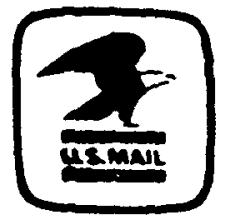

Postage and Fees Paid National Aeronautics and

Space Administration NASA-451 